\title{
A new Neogene biostratigraphy for Denmark
}

\author{
Karen Dybkjær and Stefan Piasecki
}

In Denmark most of the water used in private households, in the industry and for irrigation in agriculture comes from subsurface aquifers. Some of the most important aquifers in Jylland, western Denmark, are sand layers deposited from 23 to $15 \mathrm{Ma}$ ago, in the Early Neogene (Early to Middle Miocene). About $23 \mathrm{Ma}$ ago, in the Early Miocene, the coastline ran NW-SE across present-day Jylland (Rasmussen 2004). Global climatic variations led to major sea-level changes (Zachos et al. 2001), which in combination with increased sediment transport from the north (the present Norway) resulted in deposition of several huge, fluvio-deltaic sand systems intercalated with marine clay (e.g. Rasmussen 1961; Rasmussen 2004; Rasmussen \& Dybkjær 2005).

The Geological Survey of Denmark and Greenland (GEUS) and the regional Environment Centres (the former counties (amter)) in Jylland are working in close cooperation to study the Early Neogene succession; the main purposes are: (1) to find new aquifers, (2) to map the extent of known aquifers and clarify their mutual relationships, in order to evaluate the size of the water resources and optimise production, and (3) to protect the aquifers from pollution due to leaching from the surface.

In order to map the complex sedimentary succession, it has been necessary to combine several geological disciplines, including seismic interpretation, sedimentology, correlation of geophysical logs, and biostratigraphy (e.g. Dybkjær 2004; Rasmussen 2004; Rasmussen et al. 2004; Piasecki 2005; Rasmussen \& Dybkjær 2005; Dybkjær \& Rasmussen 2007). This article shows some results of a detailed dinoflagellate cyst stratigraphy, which is based on an extensive database (Fig. 1). We present here for the first time a dinoflagellate cyst zonation for the complete Neogene succession in the Danish area.

\section{Dinoflagellates and their cysts}

Dinoflagellates are eukaryotic, single-celled organisms that occur as motile cells with two flagella, one which encircles the cell, and one longitudinal flagellum. These organisms, which also occur abundantly at present, include autotrophs, phagotrophs, symbionts and parasites. Photosynthetic species (autotrophs) account for about half of the living genera and play an important role in the marine ecosystem as primary producers. Some marine species produce toxins or cause red tides and several types of shellfish poisoning. Dinoflagellates have left a rich fossil record, mainly of organic-walled cysts, in Mesozoic and
Cenozoic rocks; examples of fossil dinoflagellate cysts are shown in Fig. 2. Some dinoflagellate species form cysts as part of their life-cycle; others form cysts as a survival strategy, during unfavourable environmental conditions (e.g. low sea surface temperatures or lack of nutrients). The morphology of a cyst reflects the morphology of the motile dinoflagellate. The rapid evolution of the relatively complex, fossilisable dinoflagellate cyst wall makes these fossils ideal for biostratigraphic purposes (e.g. Fensome et al. 1996).

\section{Material and methods}

The dinoflagellate cyst zonation scheme presented here is based on data from more than 50 onshore and offshore boreholes and a series of onshore exposures (Fig. 1). The sediment samples from the boreholes and exposures were processed at the palynological laboratory at GEUS using standard palynological preparation methods.

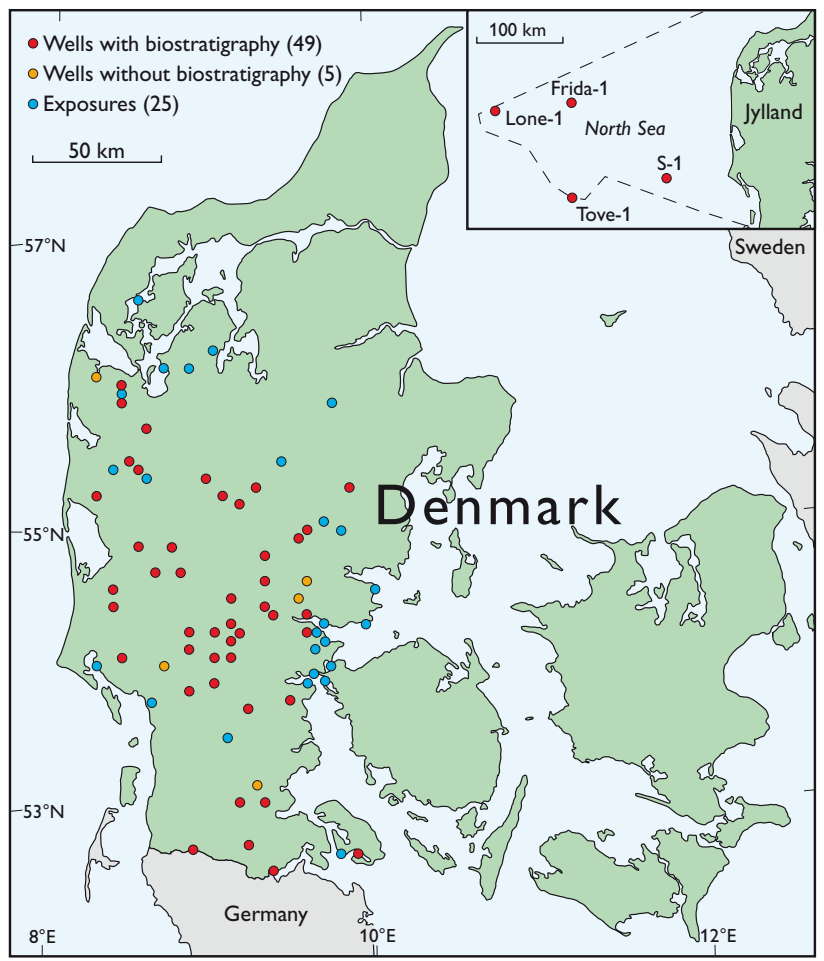

Fig. 1. Map of Denmark showing the location of studied wells and exposures. The insert map shows the location of the offshore exploration wells included in this study. 

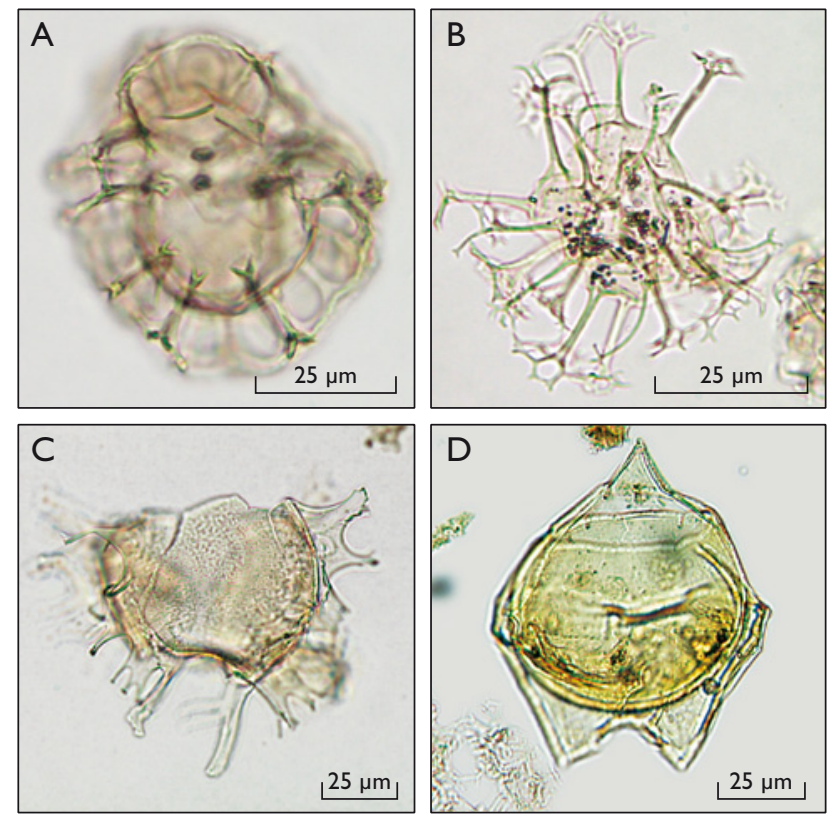

Fig. 2. Stratigraphically significant dinoflagellate cysts from the Miocene of Denmark. A: Unipontidinium aquaeductum. B: Achomosphaera andalousiense. C: Chiropteridium galea. D: Deflandrea phosphoritica.

The Danish Neogene stratigraphy has traditionally been based on molluscs and foraminifers whereas early studies of dinoflagellate floras were limited (Piasecki 1980). However, new comprehensive studies of dinoflagellate cysts throughout the Danish Neogene have resulted in a high-resolution stratigraphy of the succession, even in marginal marine deposits where foraminifers and molluscs rarely occur. Dinoflagellate cysts in strata of the central North Sea Basin were studied in offshore, hydrocarbon exploration wells, for comparison with the onshore, marginal, marine deposits and to obtain data from the youngest Neogene that is not represented by onshore strata. The resulting stratigraphy is a so-called interval zonation, i.e. all zones are defined as successions of rocks between a lower and an upper event of fossil appearance or disappearance. For example the Unipontidinium aquaeductum Zone is defined from the first appearance of $U$. aquaeductum to the first appearance of Achomosphaera andalousiense (Figs 2, 3). However, the zone is also characterised by other associated events (stratigraphic first and last occurrences of other characteristic species) and by the dinoflagellate cyst assemblage in general. Species with relatively common and consistent occurrence and with reported stratigraphic potential from outside the North Sea Basin, e.g. in the North Atlantic realm, were preferentially selected for the definition of the zones. The zonation can therefore easily be compared with other international/North Atlantic dinoflagellate zonations, despite the fact that much of the studied material was deposited in the relatively enclosed and possibly periodically brackish environments of the North Sea Basin.

\section{Dinoflagellate cyst zonation}

The Danish Neogene is formally divided into 19 dinoflagellate cyst zones from the uppermost Oligocene to the top of the Pliocene, with one zone in the Oligocene, 15 zones in the Miocene and three zones in the Pliocene (Fig. 3). The Pliocene is considered tripartite; Zanclean, Piacenzian and Gelasian (see Gradstein et al. 2004). The zonation has a high resolution in the uppermost Oligocene, the Lower Miocene and the Middle Miocene (1,8 and 4 zones respectively) and a lower resolution in the Upper Miocene and Pliocene ( 3 and 3 zones respectively). The zones will be formally defined in a forthcoming paper. The proposed dinoflagellate cyst stratigraphy for Denmark correlates well with other formal stratigraphies in the North Sea Basin, e.g. in Germany (Köthe 2003), the Netherlands (Munsterman \& Brinkhuis 2004), Belgium (e.g. Louwye et al. 1999) and the United Kingdom (e.g. Head 1998), as well as with dinoflagellate cyst stratigraphies outside this basin in the North Atlantic realm (de Verteuil \& Norris 1996), in spite of differences in selection of diagnostic species. The new Danish biozonation is also correlated with Neogene chronostratigraphy and with nannoplankton biostratigraphy (see Gradstein et al. 2004).

\section{Geological results}

The new dinoflagellate cyst stratigraphy has been extensively tested in boreholes and exposures throughout Jylland (Fig. 1). The application provides a detailed stratigraphic framework for improved geological interpretations. Three major, prograding deltaic sand systems with excellent potential as reservoirs for drinking water are recognised in the Lower Miocene to lowermost Middle Miocene in the central parts of Jylland: the Billund sand, the Bastrup sand and the Odderup Formation (e.g. Dybkjær 2004; Rasmussen 2004). In addition, several problematic issues of Neogene geology in the Danish region have been solved:

1. The stratigraphic position of the Vejle Fjord Formation (Larsen \& Dinesen 1959) is now definitively established as latest Oligocene (Brejning Clay) to earliest Miocene (Vejle Fjord Clay and Sand) (Dybkjær 2004; Dybkjær \& Rasmussen 2007). 2. The upper, silty and sandy part of the Sofienlund Formation is time equivalent to the Vejle Fjord Clay and Sand. The lower Ulstrup Clay and the Sofienlund Clay are time equivalent with the Brejning Clay (Unpublished data 2006, K. Dybkjær).

3. The Oligocene-Miocene boundary can be recognised in the eastern North Sea Basin as the last occurrence of common Deflandrea phosphoritica (Figs 2, 3). This event corresponds to the transition from the Brejning Clay to the Vejle Fjord 


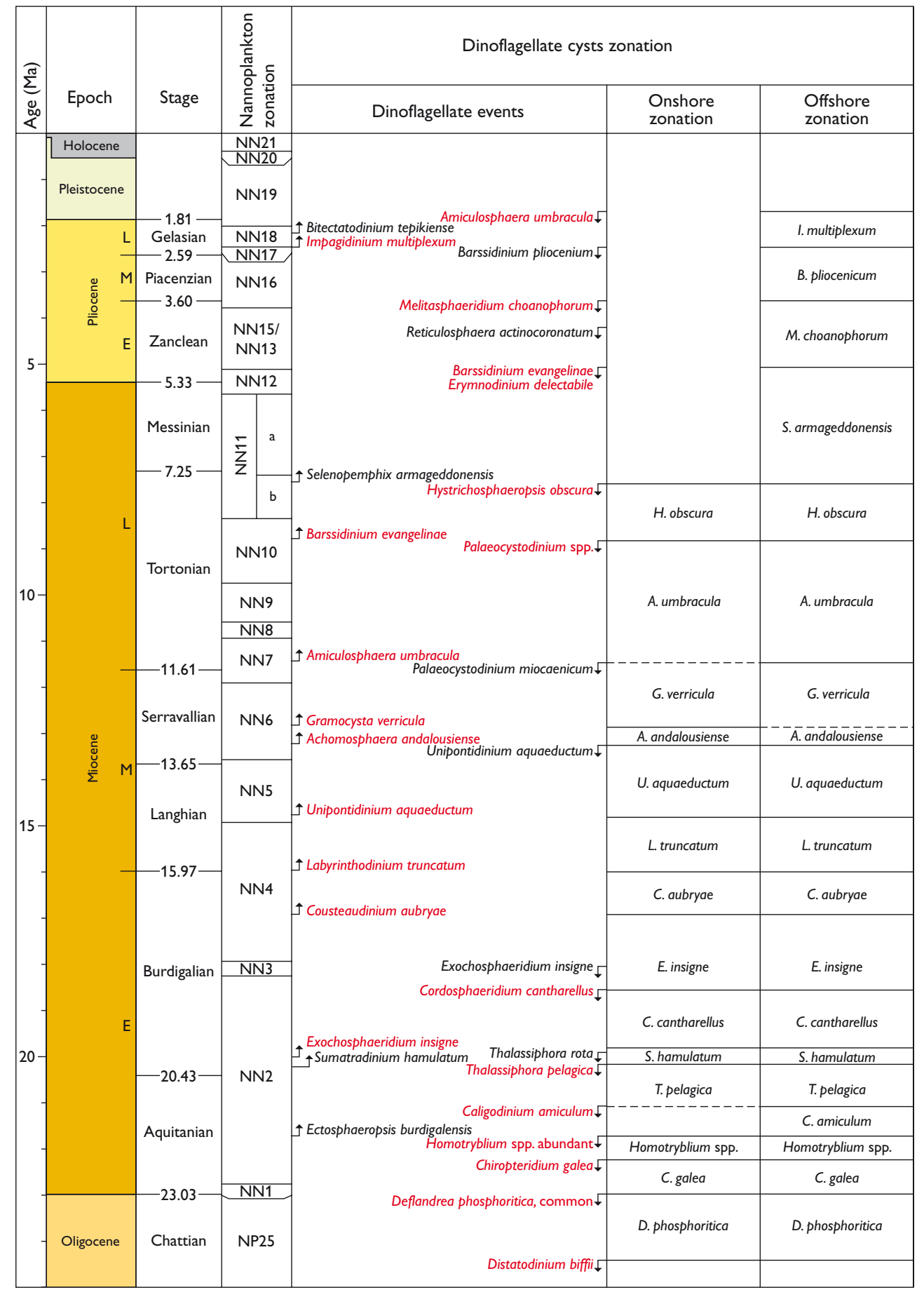

Fig. 3. Stratigraphic scheme presenting the new dinoflagellate cyst zonation correlated with the Neogene nannoplankton zonation and chronostratigraphy. The time scale is according to Gradstein et al. (2004). The diagnostic dinoflagellate cyst species are shown in red.

Clay and to the Sequence Boundary B (Rasmussen 2004; Dybkjær \& Rasmussen 2007).

4. A significant hiatus is recognised between the Vejle Fjord and Arnum Formations in the northern and central parts of Jylland. In the southern parts of Jylland a time-equivalent fluvial-deltaic sand system, the Ribe Formation, was de- posited (Dybkjær \& Rasmussen 2000; Dybkjær 2004; Rasmussen 2004; Rasmussen \& Dybkjær 2005).

5. The sand-rich succession in the Salten profile and in nearby gravel pits (Addit, Voervadsbro) was formerly referred to the late Early Miocene to early Middle Miocene Odderup Formation. Dinoflagellate cyst analysis has shown that this 
succession is older than previously assumed and is part of the Vejle Fjord Formation/Billund sand system (Rasmussen et al. 2006).

6. The Hodde transgression occurred in the early Langhian, earliest Middle Miocene and limits the age of the underlying Odderup Formation to latest Early Miocene - earliest Middle Miocene (Piasecki 2005).

7. The youngest onshore Neogene deposits are of Tortonian age (Late Miocene) as no Messinian or Pliocene dinoflagellate cysts have been recorded. The earlier Sæd Formation, upper Gram Formation sand and the Neogene sand in cliffs at Ho Bugt are considered of Tortonian age and referred to the Gram Formation (Piasecki 2005).

8. A series of maps of the Cenozoic succession in the Danish North Sea area was produced by Rasmussen et al. (2005). The age determinations of the Neogene succession are based on the dinoflagellate cyst stratigraphy presented here.

\section{Future perspectives}

The new dinoflagellate cyst zonation is not only a valuable tool for unravelling the Danish Neogene succession. The Neogene succession in Denmark is presently being correlated with other Neogene successions, e.g. in Germany, the Netherlands and Poland, in order to elucidate the Neogene geology of the North Sea Basin.

The zonation also leads to an improved understanding of the subsidence and tilting of the North Sea Basin during the Neogene, and a better understanding of the petroleum systems in the hydrocarbon-producing provinces in the North Sea area. This may lead to new discoveries and increased production from known oil/gas-fields (Rasmussen et al. 2005). It is also an important tool for solving problems such as the evidence for and the timing of the Neogene uplift of Norway.

\section{Acknowledgements}

The Danish Environment Centres and the former counties are thanked for their cooperation and financial support.

\section{References}

De Verteuil, L. \& Norris, G. 1996: Miocene dinoflagellate stratigraphy and systematics of Maryland and Virginia. Micropaleontology 42 (Supplement), $172 \mathrm{pp}$.

Dybkjær, K. 2004: Dinocyst stratigraphy and palynofacies studies used for refining a sequence stratigraphic model - uppermost Oligocene to Lower Miocene, Jylland, Denmark. Review of Palaeobotany and Palynology 131, 201-249.
Dybkjær, K. \& Rasmussen, E.S. 2000: Palynological dating of the Oligocene-Miocene successions in the Lille Bælt area, Denmark. Bulletin of the Geological Society of Denmark 47, 87-103.

Dybkjær, K. \& Rasmussen, E.S. 2007: Dinocyst stratigraphy in an expanded Oligocene-Miocene boundary section in the eastern North Sea Basin (the Frida-1 well, Denmark) and correlation from basinal to marginal areas. Journal of Micropalaeontology 26, 1-17.

Fensome, R.A., Riding, J.B. \& Taylor, F.J.R. 1996: Chapter 6. Dinoflagellates. In: Jansonius, J. \& McGregor, D.C. (eds): Palynology: principles and applications. American Association of Stratigraphic Palynologists Foundation 1, 107-169.

Gradstein, F.M., Ogg, J.G. \& Smith, A.G. et al. 2004: A Geological Time Scale 2004, 589 pp. Cambridge: Cambridge University Press.

Head, M.J. 1998: Marine environmental change in the Pliocene and early Pleistocene of eastern England; the dinoflagellate evidence reviewed. In: van Kolfschoten, T. \& Gibbard, P.L. (eds) The dawn of the Quaternary. Mededelingen Nederlands Instituut voor Toegepaste Geowettenschappen TNO 60, 199-226.

Köthe, A. 2003: Dinozysten-Zonierung im Tertiär Norddeutschland. Revue Paléobiologie, Geneve 22(2), 895-293.

Larsen, G. \& Dinesen, A. 1959: Vejle Fjord Formationen ved Brejning. Sedimenterne og foraminiferfaunaen (Oligocæn-Miocæen). Danmarks Geologiske Undersøgelse II. Række 82, 114 pp.

Louwye, S., de Coninck, J. \& Verniers, J. 1999: Dinoflagellate cyst stratigraphy and depositional history of Miocene and Lower Pliocene formations in northern Belgium (southern North Sea Basin). Geologie en Mijnbouw 78, 31-46.

Munsterman, D.K. \& Brinkhuis, H. 2004: A southern North Sea Miocene dinoflagellate cyst zonation. Netherlands Journal of Geosciences / Geologie en Mijnbouw 83, 267-285.

Piasecki, S. 1980: Dinoflagellate cyst stratigraphy of the Miocene Hodde and Gram Formations, Denmark. Bulletin of the Geological Society of Denmark 29, 53-76.

Piasecki, S. 2005: Dinoflagellate cysts of the Middle - Upper Miocene Gram Formation, Denmark. In: Roth, F. \& Hoedemarkers, K. (eds): The Gram Book. Palaeontos 7, 29-45.

Rasmussen, E.S. 2004: Stratigraphy and depositional evolution of the uppermost Oligocene - Miocene succession in western Denmark. Bulletin of the Geological Society of Denmark 51, 89-109.

Rasmussen, E.S. \& Dybkjær, K. 2005: Sequence stratigraphy of the Upper Oligocene - Lower Miocene of eastern Jylland, Denmark: role of structural relief and variable sediment supply in controlling sequence development. Sedimentology 52, 25-63.

Rasmussen, E.S., Dybkjær, K. \& Piasecki, S. 2004: The Billund delta: a possible new giant aquifer in central and western Jutland. Geological Survey of Denmark and Greenland Bulletin 4, 21-24.

Rasmussen, E.S., Piasecki, S., Andsbjerg, J., Dybkjær, K., Vejbæk, O.V., Jacobsen, C., Britze, P. \& Bryde-Auken, M., 2005: Cenozoic maps of the Danish North Sea area. Danmarks og Grønlands Geologiske Undersøgelse Rapport 2005/33, 8 pp.

Rasmussen, E.S., Dybkjær, K. \& Piasecki, S. 2006: Neogene fluvial and nearshore marine deposits of the Salten section, central Jylland, Denmark. Bulletin of the Geological Society of Denmark 53, 23-37.

Rasmussen, L.B. 1961: De Miocæne formationer i Danmark. Danmarks Geologiske Undersøgelse IV Række 4(5), 45 pp.

Zachos, J.C., Pagani, M. Sloan, L.C. Thomas, E. \& Billups, K. 2001: Trends, rhythms, and aberrations in global climate 65 Ma to present. Science 292, 686-693. 